\title{
Notes
}

\section{Possible Tool Use by Beavers, Castor canadensis, in a Northern Ontario Watershed}

\author{
D. M. BARNES
}

Joint Appointment in Department of Biology and Faculty of Forestry and the Forest Environment, Lakehead University, 955 Oliver Road, Thunder Bay, Ontario P7B 5E1 Canada

Barnes, D. M. 2005. Possible tool use by Beavers, Castor canadensis, in a northern Ontario watershed. Canadian Field-Naturalist 119(3): 441-443.

At a remote active Beaver (Castor canadensis) dam site in the Chapleau Crown Game Preserve of northern Ontario, I noted an instance where a Beaver had used a willow stem as a prop to allow it to cut other willow stems at an unrealistic height. The use of this tool (prop) meant less land foraging that in turn reduced the risk of predation and prevented undue thermal stress. This is the first account in the literature of a Beaver possibly using a tool to aid in foraging.

Key Words: Beaver, Castor canadensis, boreal forest, foraging, tool use, Ontario.

Tool use has long fascinated behavioural scientists involved in understanding animal evolution (Washburn 1960; Lancaster 1968). Over the years, researchers have documented the use of tools in insects (Wilson 1975), birds (Lack 1947; Chisholm 1954; van Lawick-Goodall and van Lawick-Goodall 1966; Morse 1968; van Lawick-Goodall 1970; Anderson 1989; Marks and Hall 1992), and mammals (Kortland 1962; van LawickGoodall 1968; van Lawick-Goodall 1970; ChevalierSkolnikoff and Liska 1993; Hart and Hart 1994; Tokida et al. 1994).

Scientists have recognized that Beavers (Castor canadensis) have the ability to construct elaborate dams, lodges, and canals. Despite these achievements, there has been only one example of tool use documented in the literature. While studying two captive Beavers at the Berne Brain Anatomy Institute, Pilleri (1983) documented an ingenious example of tool use. He kept Beavers in a concrete pool that had a constant supply of fresh water. The overflow from the pool went into a vertical metal pipe via three $0.8 \mathrm{~cm}$ holes. From a supply of twigs left for their use, the Beavers successfully cut three sticks to exact dimensions and wedged them into the three outflow holes completely stopping the flow of water.

In 1993, while conducting research on Beavers (Barnes and Mallik 1996, 1997, 2001), I documented another possible example of Beaver tool use. At a remote active Beaver dam site within the Swanson River drainage area of the Chapleau Crown Game Preserve (CCGP), $48^{\circ} 04^{\prime} \mathrm{N}, 83^{\circ} 15^{\prime} \mathrm{W}$ of northern Ontario (Barnes and Mallik 2001), I found a willow (Salix spp.) clump which had stems cut at a height of approximately $1 \mathrm{~m}$ above the ground (Figure 1). This is an extraordinary height considering that Beavers, on average, cut at an average height of $30 \mathrm{~cm}$ above the ground (Johnston

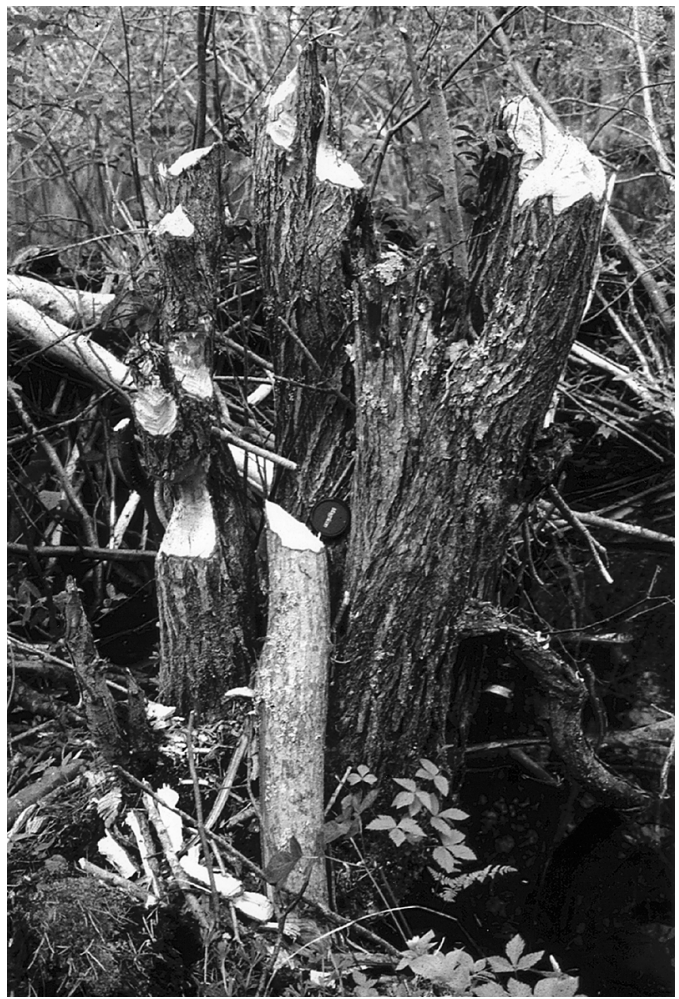

FIGURE 1. A photograph showing the Beaver's use of a willow stem as a prop to enable cutting at the elevated height above the ground. The prop is the centrally located, lighter-coloured stem supporting the camera lens cap (diameter $-6 \mathrm{~cm}$ ). Note that the Beaver has cut both the upper and lower ends of the prop; the lower end cut is hard to see due to ground cover. Unfortunately, the photograph does not show the $45^{\circ}$ leaning angle. 
and Naiman 1990; Barnes and Mallik 1997). I made a careful examination of the area and found that there was no apparent way that Beavers could have cut the stems at such a height. When I studied the willow clump more closely, I noted that there was a freshly cut willow stem, approximately $12 \mathrm{~cm}$ in diameter, leaning against the main stem of the willow clump; its approximate angle was $45^{\circ}$ (Figure 1). In addition, I observed cutting at both ends of the leaning willow segment. I first thought that the stem had fallen into place. However, this explanation does not seem possible for three reasons. First, the willow stem would have to have fallen from the overhead clump and lodged in a leaning position. When one compared colour and texture of bark, the leaning willow segment was clearly different from the stems of the willow clump (Figure 1). Second, even if we assume the willow segment came from the clump, it would have to fall from a height in order to land in the proper position. From Figure 1, cuts directly above the leaning willow are clearly too high for Beavers to harvest from ground level; i.e., approximately $1 \mathrm{~m}$. Third, the fallen stem would have had to land exactly into the correct position; i.e., $45^{\circ}$ angle and distance of $45 \mathrm{~cm}$ below the cut stems of the willow clump (Figure 1).

Another possible explanation as to why Beavers were able to cut stems at such a height may have something to do with snow levels. Northern Beavers in the late winter and early spring will often forage over snow in order to obtain fresh food along impoundments and streams (Mech 1966; Peterson 1977). To gauge the reliability of this probable scenario, one must have a better appreciation for the general area. The dam itself was $118 \mathrm{~m}$ in length and a height of $1 \mathrm{~m}$. The willow clump was located a distance of approximately $10 \mathrm{~m}$ downstream from the dam. I noted that the overflow from the dam created four smaller streams; the largest of these had an average width and depth of $1.6 \mathrm{~m}$ and $0.17 \mathrm{~m}$, respectively. In my opinion, if Beavers were to exit the waterway in winter, their most optimal strategy would have been to utilize the impoundment edge. Rue (1964) noted that in winter, water levels in Beaver impoundments often become reduced leaving air pockets along the shore, and these become convenient places for Beavers to access land. To travel overland to the willow clump the Beaver would have had to climb over the dam and wade through deep snow for $10 \mathrm{~m}$, as the downstream water channels were too small to afford any great advantage. This choice would be highly unrealistic. Barnes and Mallik (2001) showed that in the ice-free seasons, these northern Beavers forage for food trees in close proximity to water. Their study showed that Beavers harvested $71 \%$ of Trembling Aspen (Populus tremuloides) stems within $10 \mathrm{~m}$ of the impoundment edge. Beavers restricted their foraging range because of the risk of predation by Gray Wolves (Canis lupus) (Barnes and Mallik 2001).
In response to this perplexing situation, I propose an alternative explanation. I believe that a Beaver deliberately cut and transported a willow stem segment and placed it against the main stem of the willow clump. This prop enabled the Beaver to establish an elevated foraging position that facilitated the cutting of narrower stems located above the thickened stems of the clump. However, this reasoning does not explain how Beavers were able to harvest some of the highest stems (Figure 1). Like Rue (1964), I have noticed some instances where Beavers have shown surprising climbing agility. I, therefore, believe that these Beavers may well have used this prop in conjunction with other clump features to establish elevated platforms from which to cut (Figure 1).

This type of behaviour is characteristic of tool use as reported in the literature. In his treatise on the evolution of tool use in feeding animals, Alcock (1972) characterizes tool use as the manipulation of an inanimate object that improves the organism's efficiency in altering the position or form of some other object. Further, the organism should not be able to manufacture the object internally. Recently, Michener (2004) found that North American Badgers (Taxidea taxus) facilitated the capture of Richardson's Ground Squirrel (Spermophilus richardsonii) by using soil to plug their tunnels. In like manner, by using the cut stem as a prop, the Beaver was able to gain a better position to cut the higher positioned narrow willow stems. Clearly, the propped stem afforded the Beaver a platform with an optimal foraging height.

This observation is significant for two reasons: (1) this account represents the first documented case of Beavers using a tool to facilitate foraging activity; and (2) the use of a tool, from an optimal foraging perspective, provided the Beaver with an ecological advantage by reducing the foraging time on land. In boreal situations, such as the CCGP, a lessening of foraging time means reduced exposure to Gray Wolves. Potvin et al. (1992) demonstrated that Gray Wolves are highly effective predators. In subsequent studies, Basey and Jenkins (1995) further showed that Beavers actually trade off maximum profitability against minimization of Wolf predation. In addition, Beavers experience thermal stress with prolonged exposure to overland foraging activity (Barnes and Mallik 2001).

\section{Acknowledgments}

I acknowledge the financial assistance of Ducks Unlimited, the Ontario Ministry of Universities and Colleges, and Environmental Youth Corps. I am indebted to A. Mallik, Department of Biology, Lakehead University and C. Todesco of the Ontario Ministry of Resources for their guidance and logistic support. I am grateful to F. DeGagne for his technical assistance during the field work. In addition, I thank B. Barnes, Department of Biology, Lakehead University for her proof-reading skills. 


\section{Literature Cited}

Alcock, J. 1972. The evolution of the use of tools by feeding animals. Evolution 26(3): 464-473.

Anderson, S. 1989. Tool use by the Fan-tailed Raven (Corvus rhipidurus). Condor 91: 999.

Barnes, D. M., and A. U. Mallik. 1996. Use of woody plants in construction of beaver dams in northern Ontario. Canadian Journal of Zoology 74: 1781-1786.

Barnes, D. M., and A. U. Mallik. 1997. Habitats influencing Beaver dam establishment in a northern Ontario watershed. Journal of Wildlife Management 61: 1371-1377.

Barnes, D. M., and A. U. Mallik. 2001. Effects of Beaver, Castor canadensis, herbivory on streamside vegetation in a northern Ontario watershed. Canadian Field-Naturalist 115: 8-21.

Basey, J. M., and S. H. Jenkins. 1995. Influences of predation risk and energy maximization on food selection by beavers (Castor canadensis). Canadian Journal of Zoology 73: 2197-2208.

Chevalier-Skolnikoff, S., and J. Liska. 1993. Tool use by wild and captive elephants. Animal Behaviour 46: 209-219.

Chisholm, A. H. 1954. The use by birds of "tools" or "instruments". Ibis 96: 380-383.

Hart, B. L., and L. A. Hart. 1994. Fly switching by Asian elephants: tool use to control parasites. Animal Behaviour 48: 35-45.

Johnston, C. A., and R. J. Naiman. 1990. Browse selection by beaver: effects on riparian composition. Journal of Forest Research 20: 1036-1043.

Kortland, A. 1962. Chimpanzees in the wild. Scientific American 206: 128-138.

Lack, D. 1947. Darwin's finches. Cambridge University Press, Cambridge, England.

Lancaster, J. 1968. On the evolution of tool-using behaviour. American Anthropology 70: 55-66.

Marks, J. S., and C. S. Hall. 1992. Tool use by Bristle-thighed curlews feeding on Albatross eggs. Condor 94: 1032-1034.
Mech, L. D. 1966. The Wolves of Isle Royale. Fauna of the National Parks of the United States Fauna Series 7. 210 pages.

Michener, G. R. 2004. Hunting techniques and tool use by North American badgers preying on Richardson's ground squirrels. Journal of Mammalogy 85: 1019-1027.

Morse, D. H. 1968. The use of tools by Brown-headed Nuthatches. Wilson Bulletin 80: 220-224.

Peterson, R. O. 1977. Wolf ecology and prey relationships on Isle Royale. National Park Service Scientific Monograph Series Number 11. 210 pages.

Pilleri, G. 1983. Ingenious tool use by the Canadian Beaver (Castor canadensis) in captivity, Pages 99-102 in Investigations on Beavers, Volume 1. Edited by G. Pilleri. Brain Anatomy Institute, Berne, Switzerland.

Potvin, F., L. Breton, and M. MacQuart. 1992. Impact of an experimental wolf reduction on beaver in Papineau-LaBelle Reserve, Quebec. Canadian Journal of Zoology 70: 180-183.

Rue, L. L., III. 1964. The world of the Beaver. J. B. Lippincott Co., Philadelphia. 158 pages.

Tokida, E., I. Tanaka, H. Takefushi, and T. Hagiwara. 1994. Tool-using in Japanese macaques: use of stones to obtain fruit from a pipe. Animal Behaviour 47: 1023-1030.

van Lawick-Goodall, J. 1968. The behaviour of free living chimpanzees in the Gambe Stream Preserve. Animal Behaviour Monograph 1: 163-311.

van Lawick-Goodall, J. 1970. Tool-using in primates and other vertebrates. Advances in the Study of Behaviour 3: 195-249.

van Lawick-Goodall, J., and H. van Lawick-Goodall. 1966. Use of tools by the Egyptian Vulture, Neophron percnopterus. Nature 212: 1468-1469.

Washburn, S. L. 1960. Tools and human evolution. Scientific American 203: 63-75.

Wilson, E. O. 1975. Sociobiology - The new synthesis. The Belknap Press of Harvard University Press, Cambridge, Massachusetts. 697 pages.

Received 1 October 2002

Accepted 30 June 2005 